\title{
Hydrocarbon Trap and Folding Style of the Pishvar Anticline, Sub-Coastal Fars, Zagros
}

\author{
Nafiseh Hajnorouzi' ${ }^{1}$ Mohsen Pourkemani2 ${ }^{2}$ Zahra Maleki ${ }^{*}$ \\ ${ }^{1}$ Department of Geology, Science and Research Branch, Islamic Azad University, Tehran, Iran \\ ${ }^{2}$ Department of Geology, North Tehran Branch, Islamic Azad University, Tehran, Iran \\ Email: ${ }^{*}$ z.maleki@srbiau.ac.ir
}

Received 20 October 2015; accepted 19 June 2016; published 22 June 2016

Copyright (C) 2016 by authors and Scientific Research Publishing Inc.

This work is licensed under the Creative Commons Attribution International License (CC BY). http://creativecommons.org/licenses/by/4.0/

c) $\underset{\mathrm{EY}}{\mathrm{i}}$ Open Access

\section{Abstract}

The Pishvar anticline with Northwest-Southeast trend is located in the Sub-Coastal Fars area. This anticline with $80 \mathrm{Km}$ length and $5-7 \mathrm{Km}$ width is located in western part of the Lar area. The Pishvar anticline has two closures that are separated together by smooth down-warp. The oldest units that have outcropped on the surfaces are Asmari and Jahrom Formations. The most faults that observed on the Pishvar anticline are Normal fault. In the study area, the Razak and Hendurabi faults are main faults. These faults are strike slip with sinistral displacement. This anticline has greater dip in Northern flank compared to Southern flank. In this research, the main aim is folding style analysis, based on Description of fold geometry for indicate hydrocarbon trap structure in the Pishvar anticline. Description of fold geometry is important because they allow comparisons within and between folds and pattern-recognition in addition to occurrence and distribution of fold systems. We used Tectonics FP and Global Mapper Software for prepared some data in our study. In addition, we used the common classification of folds for our research. Based on results, the folding pattern of this anticline has indicated the fold style has different type in different parts of the Pishvar anticline. According to fold style variation and deformation analysis from B-B' to C-C' parts of the study anticline, it seems that the location of the Razak sinistral strike slip fault has existed in this parts. Fold style change can show this case. In addition, fold style variation and deformation analysis from E-E' to F-F' parts of this anticline has been affected of the secondary fault that is related to the Razak sinistral strike slip fault. We introduced this fault for first time. Finally, Based on results in this research, in western part there is little probability for access to hydrocarbon trap in upper horizons, unless the exploratory drilling continues to the deeper horizons.

\section{Keywords}

Pishvar Anticline, Fold Style, Razak Faults, Hydrocarbon Trap

\footnotetext{
${ }^{*}$ Corresponding author.
} 


\section{Introduction}

Middle East countries have 60 percent of the world's oil and 40\% natural gas reservoirs definitive reservoirs in the world. In terms of oil and gas sources in the Middle East, Iran has the world's second and third rank respectively. Actually $10 \%$ of the Earth's oil (5/132 billion barrels) and 16 percent of the discovered gas (971 trillion cubic feet) located in the Iran country. Middle East reservoirs have been discovered in 60 years, have mainly Mesozoic age, structural type traps, carbonate reservoir rocks and reservoir depth average (less than $5.4 \mathrm{~km}$ ) with recyclability [1]. The majority of Iran's reservoirs are located in the Zagros Folded Belt and the Persian Gulf basin. Because of enormous gas reserves Exists in the Permo-Triassic carbonate reservoirs of the Zagros Folded Belt, therefore anticlines in this belt have the major significance from hydrocarbon traps reservoirs, especially in the Fars area. For this reason, investigation of oil traps of the oil-rich areas is very important to analyze the factors influencing the evolution and geometry of the anticlinal structures Zagros foreland area, especially the folding mechanism analysis.

The Pishvar anticline is located in the Lar area (117 km to Persian Gulf) (Figure 1). The age of Hormuz Series is Pre-Cambrian-Cambrian. The oldest units that have outcropped on the surfaces are Asmari and Jahrum Formations. This anticline is an asymmetric structure, which has $80 \mathrm{~km}$ length and 3 - $7 \mathrm{~km}$ width in the Mishan,
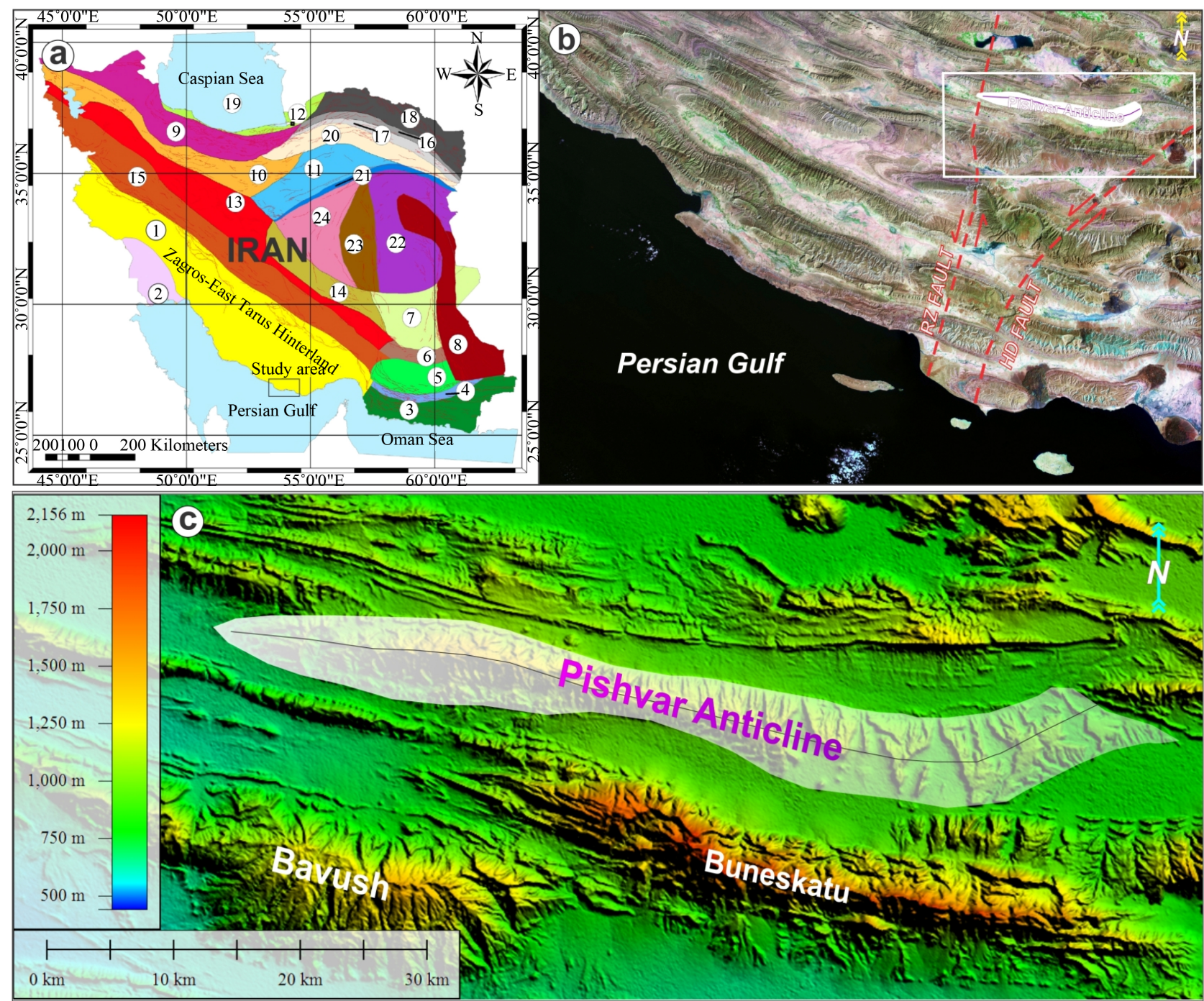

Figure 1. (a) This map showslocation of the study area (black rectangular) in the Physiographic-tectonic zoning map of Iran's sedimentary basin [6]; (b) Landsat Satellite image shows the study area and location of the Pishvar anticline in the Zagros fold-thrust belt, southern of Iran; (c) SRTM image of the study area shows the Pishvar anticline. 
Gachsaran Formations on the surface (Figure 2 and Figure 3). The most surface of anticline is generally covered with Mishan and Gachsarn Formations. The study area is located in the southern part of the Zagros folded belt and geology of the Fars province. Based on the geology, the Fars province is divided based on the basis of stratigraphic facies characteristics, sedimentary and geological environment into two parts the Interior Fars and Exterior Fars. Accordingly, the Exterior Fars is divided into two Sub-Coastal Fars and Coastal Fars sub-zones [2]. Hendurabi and Razak main faults are the main faults in the study area. This anticline has been affected by these faults. It seems that, the separator factor of the anticline that caused the Bayram anticline has been divided from the Gavbast anticline is the $\mathrm{R}$ fault. The Razak fault in the study area considered as eastern boundary from the Gavbandi Paleo-high [2] [3].

The Fars area has been a platform, and this area has been suffered repeated uplift during the Mesozoic. The Paleo-High Gavbandi has been affected on this area [3]. Based on obtained information from seismic reflection profiles and hydrocarbon exploration wells, the sedimentary cover has important detachment units between competent units in different parts of the Zagros Fold Belt. These detachment units have been controlled on the geometry and the folding style. The main detachment units in this belt are Dashtak, Gachsaran formations. For instance important detachment units around the Zagros folded belt are lower Paleozoic shales. Also in the Coastal Fars sub-basins, the Triassic shales (Dashtak Formation) are one of the most important detachment units (Figure 2) [4].

The first geological report for exploratory drilling in the Pishvar anticline dated back to the 2001 by the National Iranian Oil Company (NIOC). Based on give results for hydrocarbon exploration, in western part of this anticline the Dariyan horizon is dry in $1416 \mathrm{~m}$ depth. May be for hydrocarbon exploration drilling has been continued to Dehram horizon has been Continue drilling, the Oil Company achieved huge hydrocarbon in the future. The Dehram horizon has three main stratigraphic units (Faraghoun, Dalan and Kangan Formations). This main horizon has important Reservoir characteristics. In this research, the main aim is folding style analysis, based on description of fold geometry for indicate hydrocarbon trap structure in the Pishvar anticline. Description of fold geometry is important because they allow comparisons within and between folds and pattern-recognition in addition to occurrence and distribution of fold systems.

For the first time, O’Brien (1950) [5] shows that the effects of detachment layers on folding process. In addition, other researchers have discussed about this case too, e.g. [6]-[23].

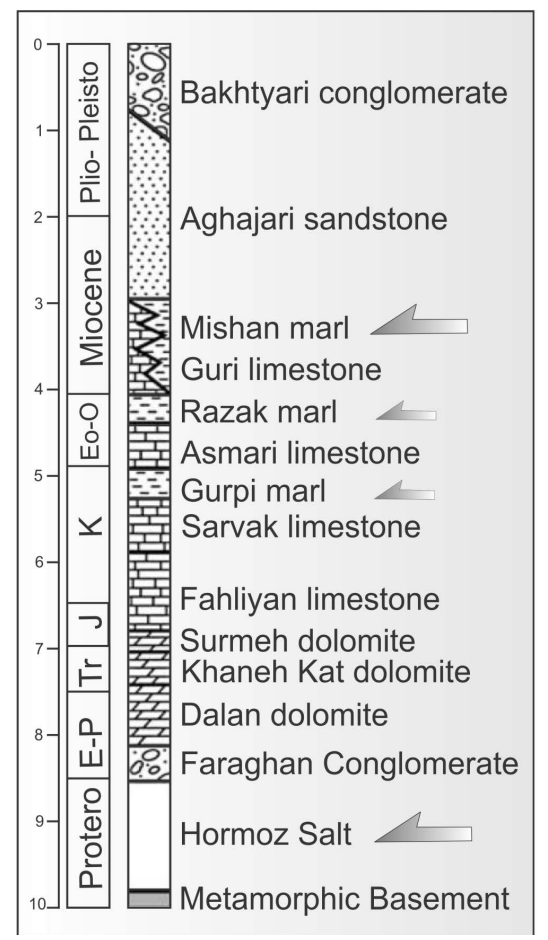

Figure 2. The simply stratigraphic column of the Study area [2]. 


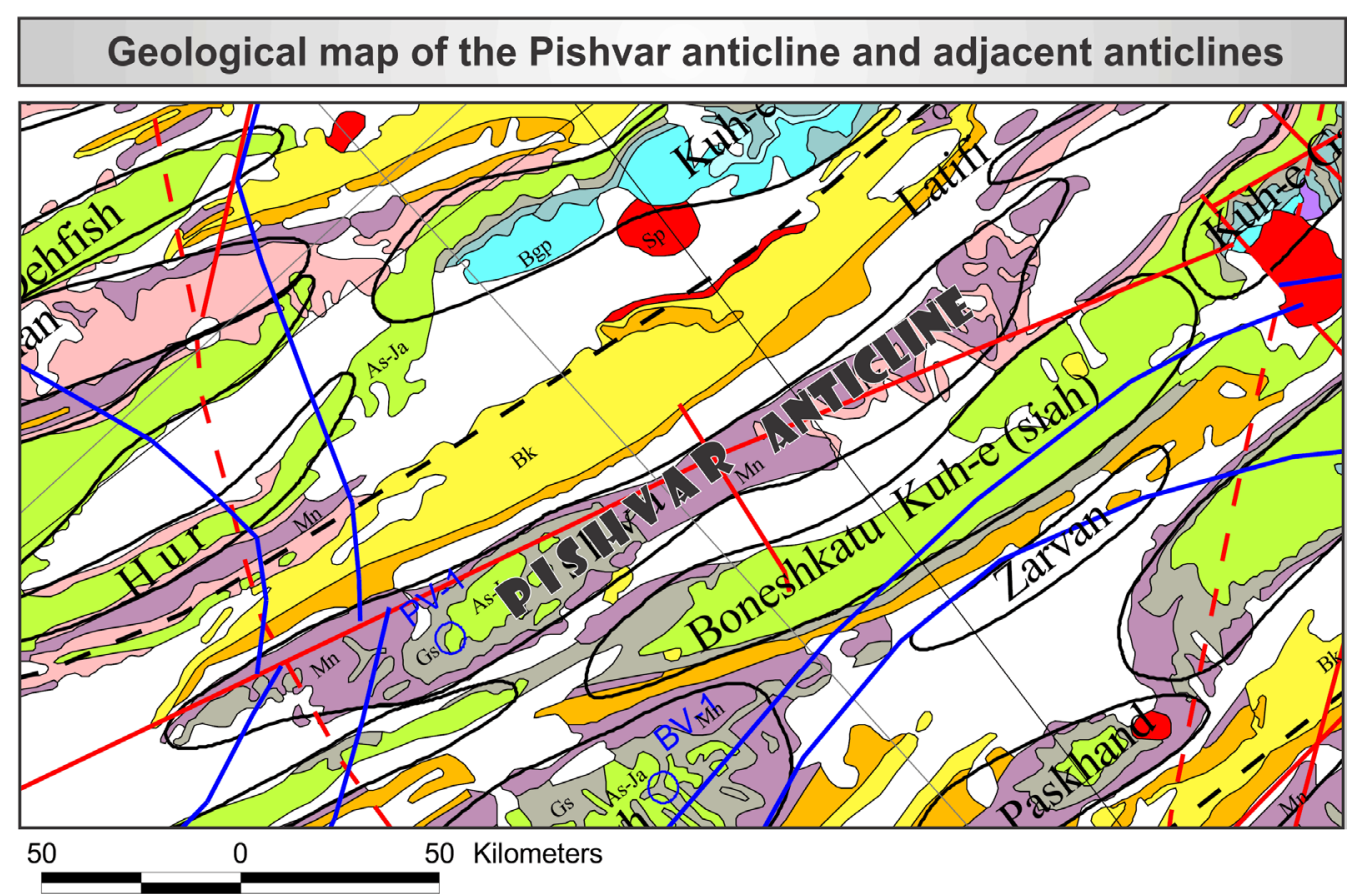

LEGEND OF GEOLOGICAL MAP

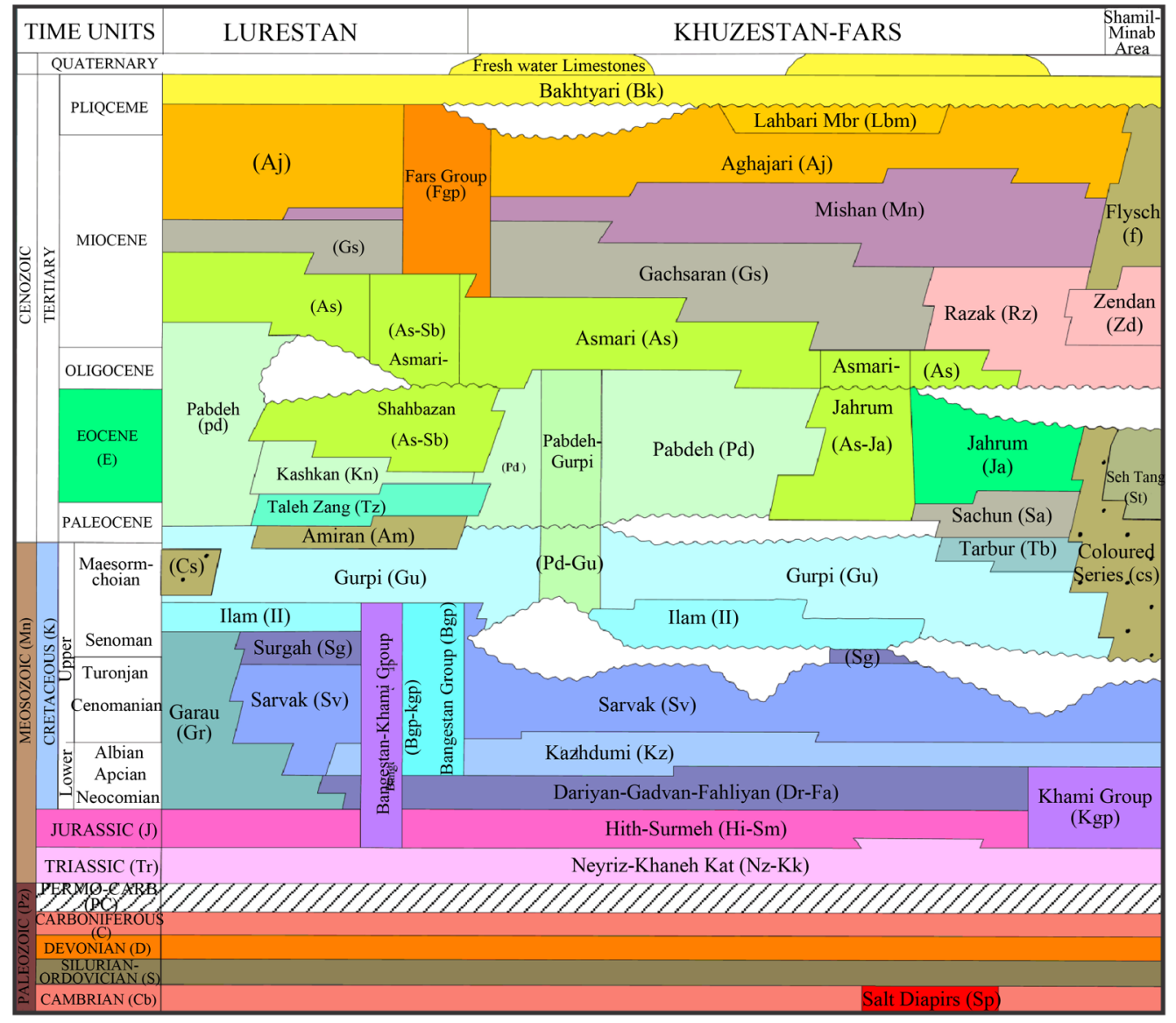

Figure 3. This map shows the study area and the pishvar anticline, based on geological map (modified after [29]). 


\section{Material and Methods}

This paper presents part of the results of a regional study of the Sub-Coastal Farsarea in the Zagros Simply folded belt, based on original fieldwork, satellite images, structural sections, geological maps and well data. We used fold style elements analysis methods (description of folds) based on [24]-[27]. We used Tectonics FP software for prepared and analyzed Stereoplots of the Pishvaranticline. In addition, we used Global Mapper Software for prepared 3D SRTM of the study area and 3D Path Profile (along cross sections) based on Global Mapper Software. 3D SRTM prepared based on Digital Elevation Model (DEM) and geological map of study area (published by the National Oil Company and the Geological Survey of Iran). In this research, we used Tectonics FP and Global Mapper Software for prepared some data in our study. In addition, we used the common classification of folds for our research.

\section{Geological Setting and Stratigraphy}

In this paper, the Study area is located in the Zagros orogenic belt. The Zagros fold and thrust belt was formed by collision of two tectonic plates the Eurasianor Iranian and Arabian Plates. In this belt, the Sub-Coastal Fars region, based on geological fancies units perpendicular to Zagros belt was divided into the Interior Fars, SubCoastal and Coastal Fars sub-basins [2] and the study area is located in the Sub-Coastal Fars sub-basin. This area is easily recognized by the NW-SE orientation parallel anticlines that verge to the SW in a $6-12 \mathrm{~km}$ cover sequence [30]. Anticlines outcropping stratigraphic units in the most of structures Sub-Coastal Fars region often include Upper Cretaceous stratigraphic units (Maestryshtyn-Campanian to the present) and in the sub-coastal region, includes the Lower Cretaceous stratigraphic units (Neocomian to the present). The Pishvar anticline is located in the Lar area of the Fars province (117 km to the Persian Gulf). Based on Setchell et al. (2007) [28], the Pishvar anticline is fault bend fold.

The Pishvar anticline has Northwest-Southeast trend. This anticline is bounded from North-Northeast by the Kuh-e Parakand Kurdehanticlines, from South-Southeast by the Boneshkatu anticline, from east Kuh-e Gach and from Northwest-Southwest by the Hur and Khong anticlines. The Pishvar anticline is an asymmetric structure, which has $80 \mathrm{~km}$ length and 5 - $7 \mathrm{~km}$ width on the surface (Figure 1 and Figure 3).

\section{Main Faults in the Study Area}

The Zagros fold-thrust belt (ZFTB), in Southwest Iran, exposes extensive areas of deformed Cambrian to Holocene sedimentary rocks with minimum vegetation cover (e.g., [30]-[32]). This Phanerozoic sequence has folded and faulted above the crystalline Precambrian basement, forming large (approximately $104 \mathrm{~m}$ ), doubly plunging asymmetric folds that host vast volumes of hydrocarbons in anticlinal traps. The Zagros fold-thrust belt has main basement faults or active deep-seated faults. Recent work by [30]-[32] shows that basement faults such as the Oman, Bastak, Bostaneh, Hendurabi, Razak, Sarvestan, and Kazerun faults mapped by field observation and integration of geomagnetic maps with remotely sensed data, align with some of the domain boundaries, which were delineated in this study based on the fracture analysis, and the regional changes in the fold axial traces. The changes in the axial traces, from the general NW-trending in the Fars region to the EW-trending in the Lorestan, and toward the Bandar Abbas region, can be explained by the presence of active deep-seated faults [30]-[32]. The development of these fault zones in the sedimentary cover, their relation to the inherited and active basement faults and their importance in the hydrocarbon exploration is discussed [30] [31].

The main faults in the study area are the Razak and Hendurabi fault (Figure 3(b)). The Razak fault was first introduced by Barzegar (1994) [32], based on satellite images in southern Iran. This fault has $230 \mathrm{~km}$ long and NNE-SSW trend. This researcher [33] [34] has considered this fault as a basement fault. This researcheris considered the main control factor on the Hormuz salt basin in paleo-environment was the Razak Fault and the activity of this fault belongs to Cambrian to Late Pliocene reports. The Razak fault can be seen as a line structural feature in the geological map of the surface. This fault in the basement is clear with regard to its role in the development of the Gavbandi paleo-high as well as the western border of the salt dome in the Fars area and Zagros fold-thrust belt. In Figure 3, the Razak Fault is clearly visible on the map and its effects. Based on [4] indicates that the Razak fault is a passive fault formed only as a result of variation in the folding style caused by changes in thickness of the folded strata as it moves onto the basement high across this lineament. The main activity along this basement lineament was during the Early Paleozoic. 
One of the main faults in the study area is the Hendurabi fault. A few researchers [33] [34] studied the Hendurabi fault. This fault with Northeast-Southwest introduced as a basement fault based on satellite images interpreted the changes in the geometry and style of deformation. It seems that in the study area, folding style and variation of structural style created affect by the Razak and the Hendurabi sinistral strike slip fault. On the other hand, fold, with close sideways require special attention as structural view and this type fold can be indicated more deformation created by main faults in the study area. Based on results of elements of fold style analysis can be analyzed deformation in the study area.

\section{The Description of Folds}

Description of fold geometry is important because they allow comparisons within and between folds and allow us to recognize patterns in the occurrence and distribution of fold systems. For example, orogenic belts contain characteristic fold systems: along their flanks are large fold and thrust belts, with little metamorphism, but underlain by décollements; and in core zones where intense folding has accomplished, accompanied by high-grade metamorphism under high temperature and pressure. According to Ragan (2009) [27], Folds, which close sideways, are neutral and these require special attention. In this anticline, based on folding angle from A-A' to C-C' sections (range between $74^{\circ}-106^{\circ}$ ) fold type are open and from D-D' to G-G' sections (range between $110^{\circ}$ $140^{\circ}$ ), fold type are close. Based on Ragan [27], it should be special attention to this style.

\section{Elements of Fold Style}

The style of a fold is the set of characteristic that describe its form. Over years of working with folds, geologists have identified certain features as particularly useful in describing fold and understanding how they develop [24].

Because the Pishvar anticline for oil exploration targets is important and in the previous drilling is dry, thereforethe analysis of fold style elements is seems necessary. For more studies on this structure, the changes of fold style elements will be analyzed and investigated from east to west in the different parts of this anticline. Because of the Razak fault may be effect on the west parts of the Pishvaranticline, we have evaluated and calculated some elements of fold style, measurable in this structure. In this respect, symmetry, cylindricity, Geometry of axial plane and Folding Mechanism have been evaluated. Figure 4 is show location of the studied structural cross sections on the Pishvar anticline.

\subsection{Symmetry}

A folded surface forms a symmetric fold if in profile, the shape on one side of the hinge is a mirror image of the shape on the other side, and if adjacent limbs are identifiable in length [25]. The study anticline is an asymmetric

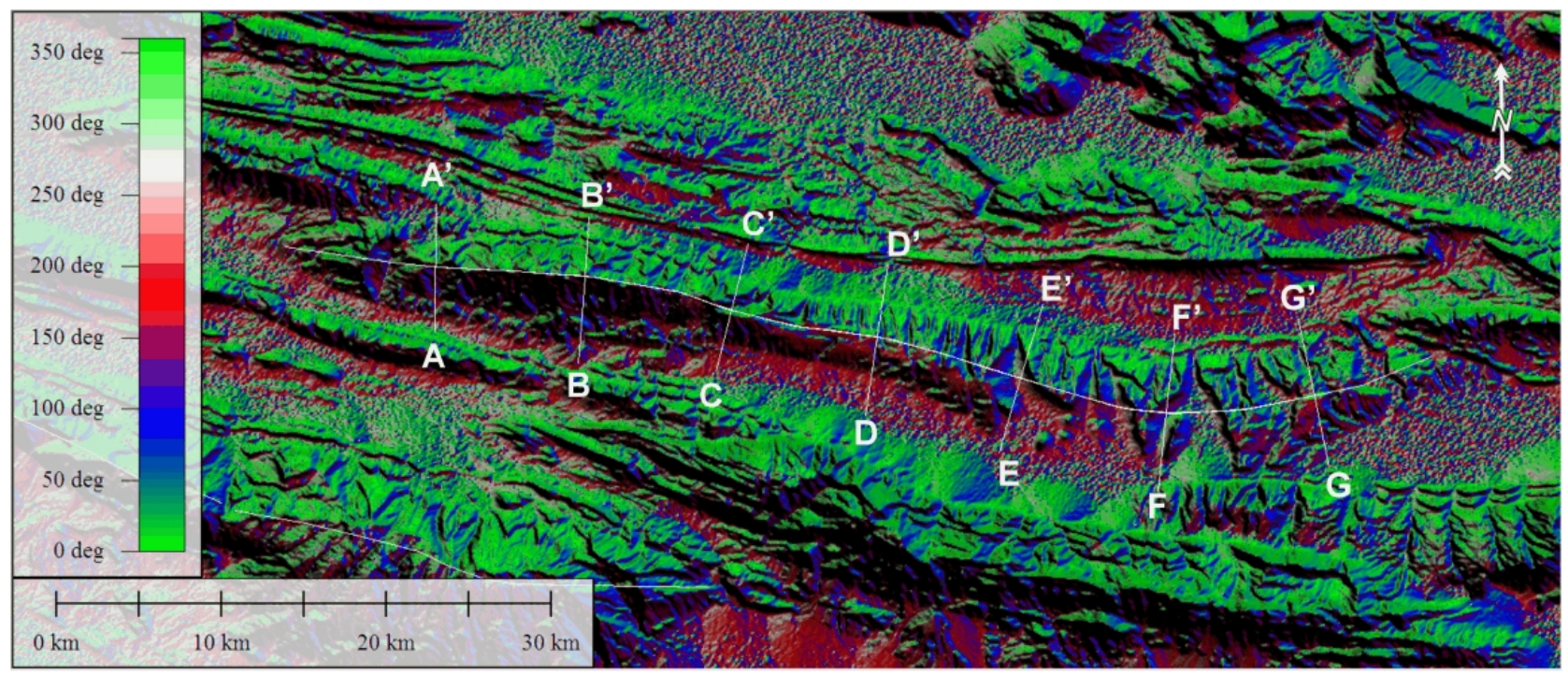

Figure 4. Location of the studied structural cross sections on the Pishvar anticline. 
fold with changed plunge in the north of the western part of fold. The Pishvaranticline is an asymmetric anticline. Based on results, this anticline is an asymmetrical anticline in which the dip of Northern flank in A-A' to D-D' is greater than the Southern flank and dip of Southern flank in E-E' to G-G' is greater than the Northern flank.

\subsection{Cylindricity}

The Cylindricity is represented qualitatively on a stereonet by how closely the poles to planes around a fold fit a great circle distribution [24]. The studied anticline is a cylindrical to conical fold with changed plunge in the north of the western part of fold. The output of Tectonics FP software for seven parts of the Pishvar anticline is shown in Figure 5.

\section{Classification of the Fold}

Based on Twiss and Moors method (1992) [24] for description of fold, seven stereoplots (output of Tectonics FP software) were prepared for seven parts of the Pishvaranticline. According to results, these stereoplots show the location of axial plane (AP) and cylindricity (AC) and Plunge of Fold (P) (Figure 5). This part to be done based on seven structural cross sections of the Pishvaranticline and geological data. The locations of these structural cross sections (from A-A' to G-G') is shown in Figure 5.

According to description of fold [30] for seven sections in the Pishvaranticline (from A-A' to G-G'), the geometry of axial plane is planer. Also from B-B' to C-C', dip of axial toward SW) and in the A-A', D-D' to G-G' dip of axial plane toward NE) (Figure 5). It seems that these changes affected by sinistral displacement of Razak fault. For more explanation, based on orientations of axial plane, see Figure 5. Change of dip of axial plane from B-B' to C-C' toward SWand A-A', D-D' to G-G' toward NE confirms sinistral displacement of Razak fault and effect of this fault on the geometry of axial plane.

In the seven structural cross sections of the Pishvaranticline, dip value of axial plane is changing from $78^{\circ}$ to $89^{\circ}$. Based on classification of Ramsay (1967) [25] for fold classification and changes of axial plane in different parts of anticline, the fold type in the D-D' and E-E' are different from other parts. Based on classification of Ramsay (1967) [25], in most parts of the Pishvaranticline, axial plane of fold is upright but in C-C' type of the axial plane is steeply inclined. May be sinistral displacement of the Razak fault has caused this change in this anticline.

Based on the classification of Rickard (1971) [26], In E-E' and F-F' parts of this anticline, type of fold is upright-plunging (Figure 6). Also, in the C-C' is inclined-horizontal and it is completely different from other parts of the study anticline. In other parts of this anticline, fold type based on classification of Rickard (1971) [32], fold type is upright horizontal. In this part, based on classification of Ramsay [25], in the different parts of the Pishvar anticline, type of fold is variable and four types are recognize (Figure 7). In E-E' and F-F' parts of this anticline, type of fold is upright-gently plunging. Also, in the C-C' is steeply inclined- sub horizontal and it is completely different from other parts of the study anticline. In other parts of this anticline, fold type based on classification of Ramsay [25], fold type is upright- sub horizontal.

According to these results, it seems that folding mechanism in the Pishvar anticline, it seems that from B-B' to C-C', the Razak fault has caused main changes on the fold style and maybe secondary fault that related to the Razak fault affected on the fold style and mechanism of folding. Because of the study anticline parts from A-A' to C-C' is open type (from eastern part to middle part) and from D-D' to G-G' is close type. Based on these results (Twiss and Moors classification (1992) [24]), the Pishvar anticline has been suffered more deformation from middle toward eastern part. In previous oil exploration, report from National Iranian Company (2001) in western part of this anticline the exploratory well in Dariyan horizon is dry in $1416 \mathrm{~m}$ depth. Based on results in this research, in western part is little probability for access to hydrocarbon trap in upper horizons, unless the exploratory drilling continues to the deeper horizons.

\section{Conclusions}

The change of dip of axial plane from B-B' to C-C' toward SW and A-A', D-D' to G-G' toward NE confirms that sinistral displacement of Razak affected on the geometry of axial plane. Also in most part of axial plane of fold, axial planes upright but in C-C' type of the axial plane type is steeply inclined. It seems that sinistral displacement of the Razak fault has caused this change in this anticline. Based on results, the Pishvar anticline has 


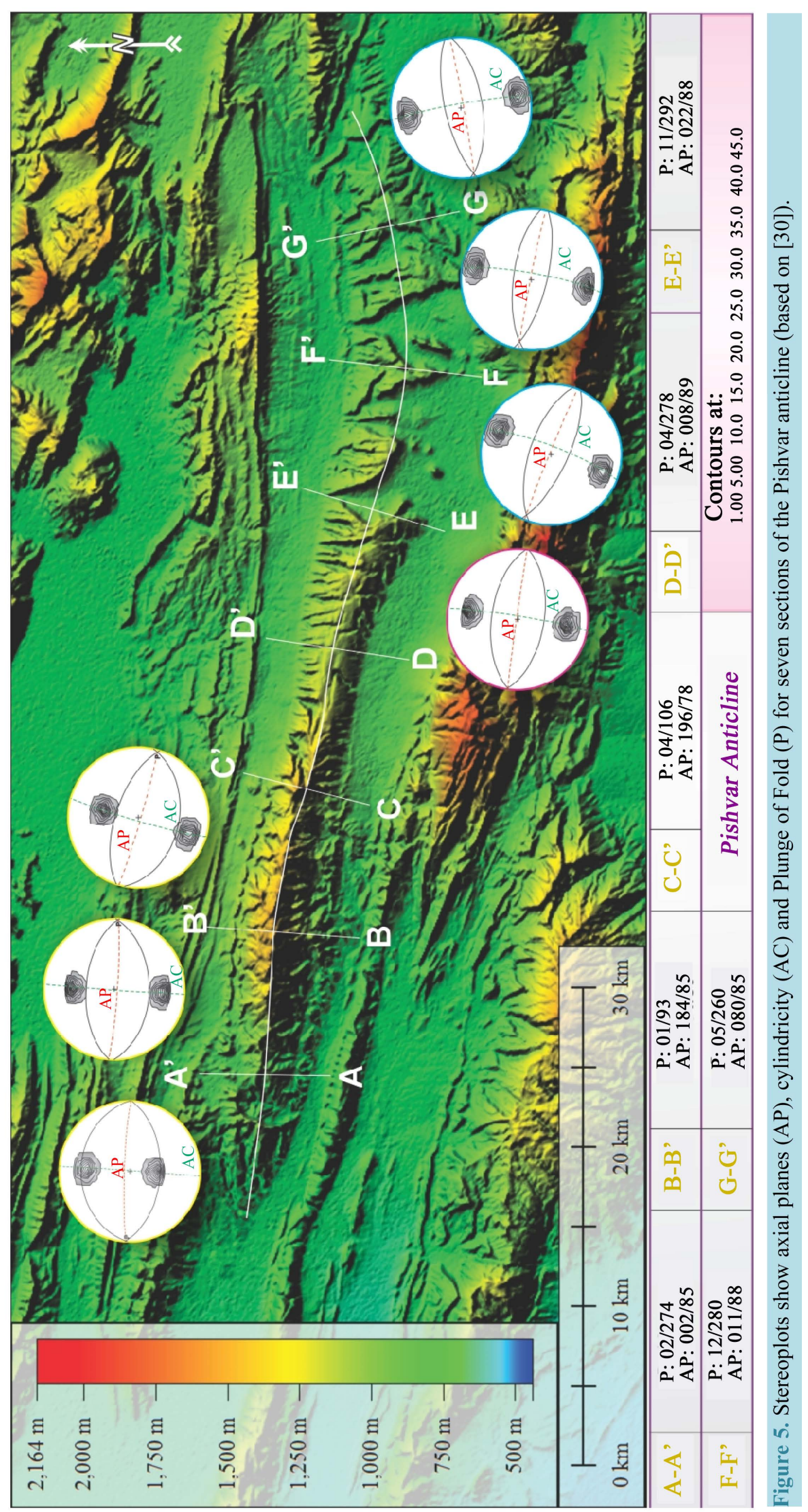




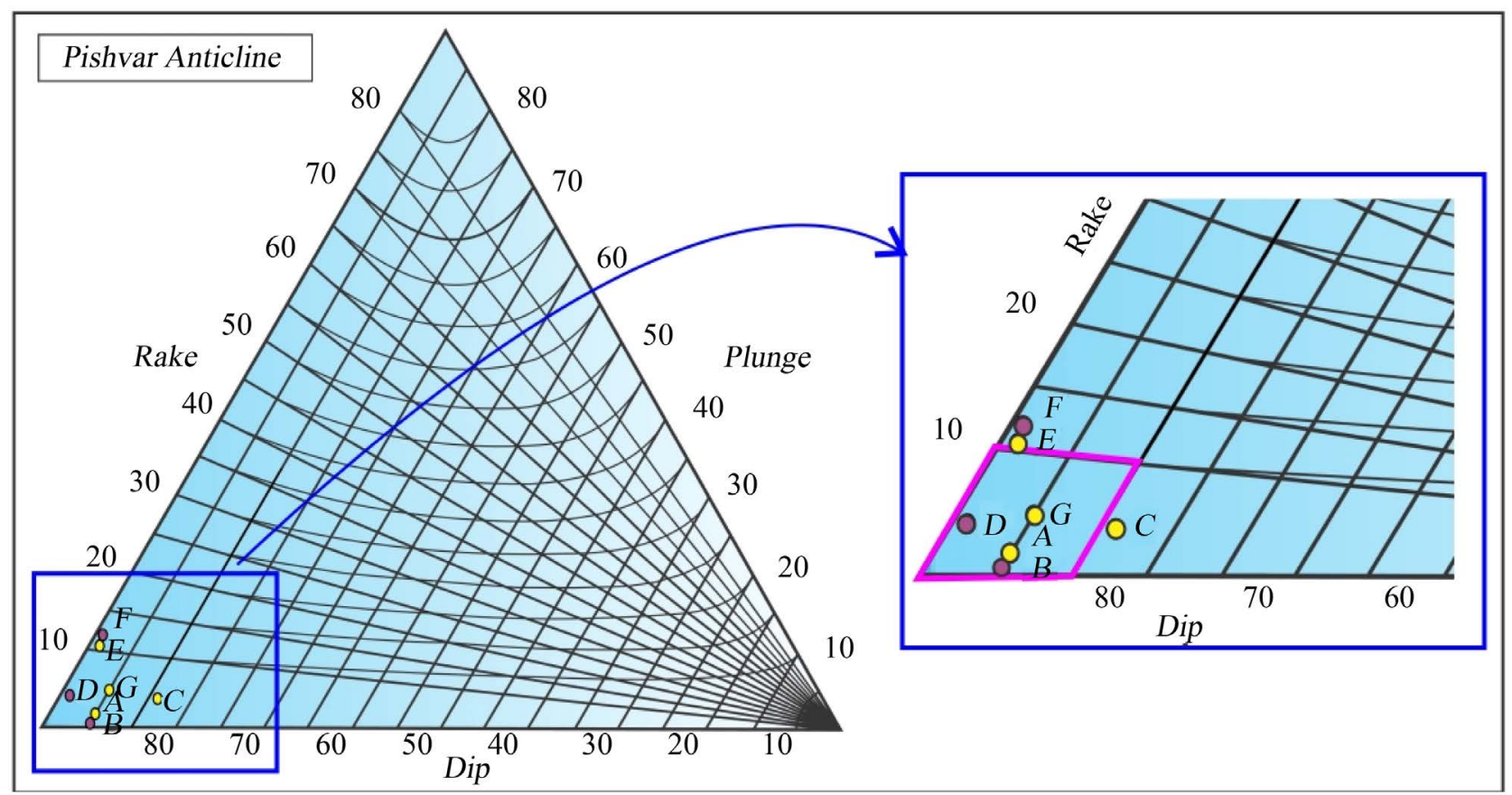

Figure 6. Triangle form diagram shows type of fold in seven sections of the pishvar anticline, based on [26]. Type of fold in part G (G-G' section) is different to other section completely.

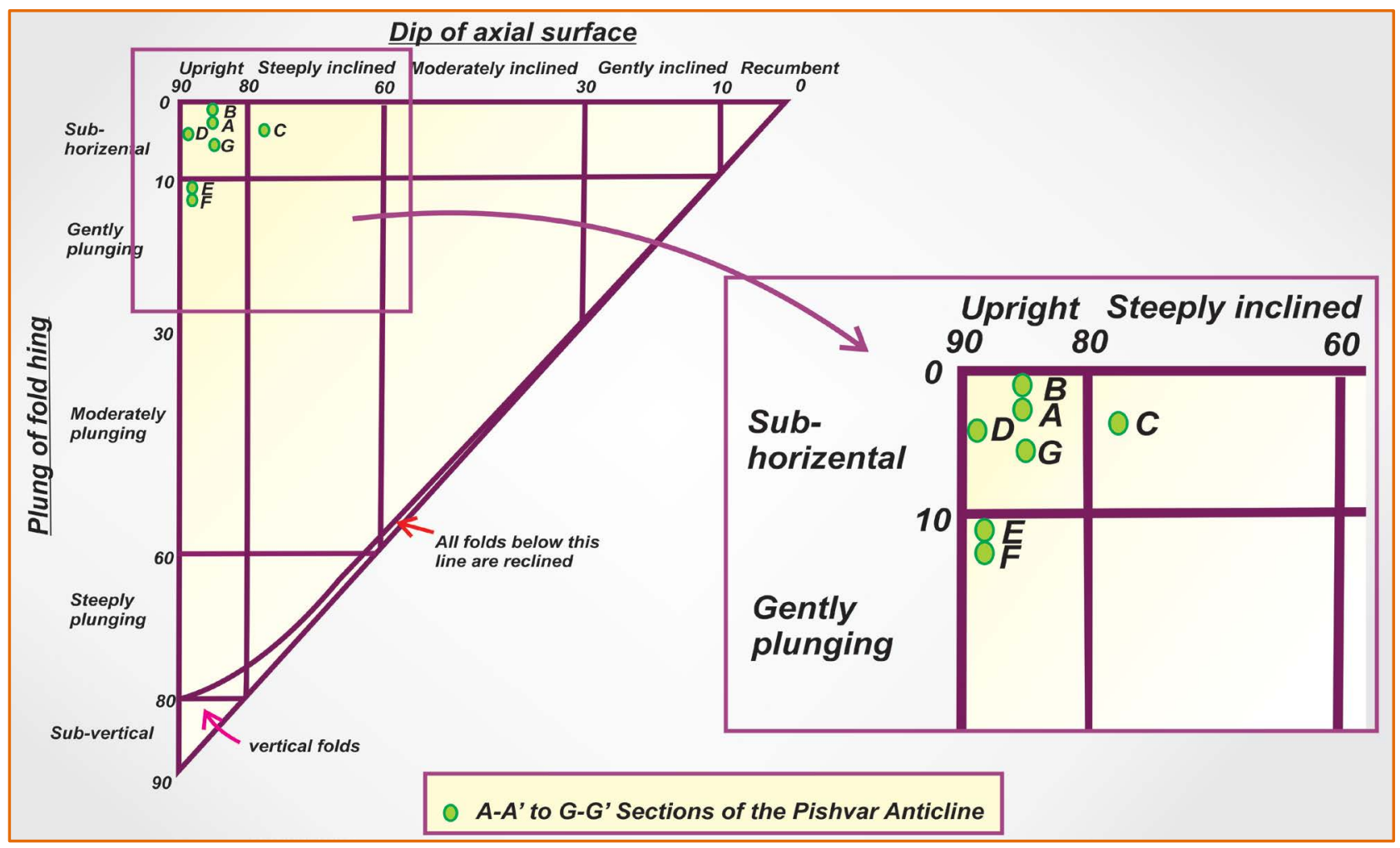

Figure 7. This figure shows the classification for orientation of the Pishvar anticline based on [25].

been suffered more deformation from middle toward eastern part. In previous oil exploration, report in western part of this anticline the exploratory well in Dariyan horizon is dry in $1416 \mathrm{~m}$ depth. Based on results in this 
research, in western part is little probability for access to hydrocarbon trap in upper horizons, unless the exploratory drilling continues to the deeper horizons.

Based on fold style variation and deformation analysis from B-B' to C-C' parts of the study anticline, it seems that the location of the Razak sinistral strike slip fault has existed in this parts. Fold style change can show this case. In addition, fold style variation and deformation analysis from E-E' to F-F' parts of this anticline has been affected of the secondary fault that is related to the Razak sinistral strike slip fault. We introduced this fault for first time. Finally, based on results in this research, in western part is little probability for access to hydrocarbon trap in upper horizons, unless the exploratory drilling continues to the deeper horizons.

\section{Acknowledgements}

The authors acknowledge the Department of geology, Islamic Azad University, Science and Research branch, Tehran, Iran for funded this project. In addition, we thank Vice-President for Research in Science and Research branch, Tehran.

\section{References}

[1] Horn, M.K. (2003) Giant fields, 1868-2003 (CD-ROM). In: Halbouty, M.T., Ed., Giant Oil and Gas Fields of the Decade 1990-1999: AAPG Memoir 78.

[2] Motiei, H. (1993) Stratigraphy of Zagros. Treatise on the Geology of Iran. Ministry of Mines and Metals, Geological Survey of Iran, Tehran.

[3] Setudehnia, A. and Perry, J.T. (1965) Geological map of SE \& SE Fars, Scale 1: 250,000. National Iranian Oil Company, Tehran.

[4] Motamedi, H., Sherkati, Sh. and Sepehr, M. (2012) Structural Style Variation and Its Impact on Hydrocarbon Traps in Central Fars, Southern Zagros Folded Belt, Iran. Journal of Structural Geology, 37, 124-133. http://dx.doi.org/10.1016/j.jsg.2012.01.021

[5] O’Brien, C.A.E. (1950) Tectonic Problems of the Oil Field Belt of Southwest Iran. Proceedings of 18th International of Geological Congress, Great Britain, Part 6, 45-58.

[6] Maleki, Z., Arian, M., Solgi, A. and Ganjavian, M.A. (2014) The Elements of Fold Style Analysis in the Khaftar Anticline, Zagros, Iran. Open Journal of Geology, 4, 79-92.

[7] Maleki, Z., Arian, M. and Solgi, A. (2014) Structural Style and Hydrocarbon Trap of Karbasi Anticline, in the Interior Fars Region, Zagros, Iran. Solid Earth, 6, 2143-2167.

[8] Maleki, Z., Arian, M., Solgi, A. and Ganjavian, M.A. (2013) Sediment Deformations on Strike Slip Fault Blocks and Analogue Modeling: A Case Study of Nezamabad Fault, Interior Fars, Zagros. Journal of Sciences, Islamic Azad University. (In Persian)

[9] Arian, M. and Maleki, Z. (2014) Principals of Experimental Tectonics. Asar-e Nafis Publication, Tehran, 224 p.

[10] Maleki, Z., Arian, M. and Solgi, A. (2015) Folding Pattern in the Fars Province, Zagros Folded Belt: Case Study on the Karbasi and Khaftar Anticlines, Interior Fars, Iran. Solid Earth Discussions, 7, 2347-2379. http://dx.doi.org/10.5194/sed-7-2347-2015

[11] Maleki, Z. and Jahadgar, F. (2015) Folding Style of the Kuh-e Siah Anticline in the Sarvestan Area, Interior Fars, Zagros, Iran. Open Journal of Geology, 5, 552-561.

[12] Maleki, Z. (2015) The Unique Folding Style in the Zagros Simply Folded Belt, the Kuh-e Qazi Anticline, South Iran. Open Journal of Geology, 5, 514-526.

[13] Maleki, Z., Arian, M. and Solgi, A. (2014) Structural Style and Hydrocarbon Trap of Karbasi Anticline, in the Interior Fars region, Zagros, Iran. Solid Earth Discussions, 6, 2143-2167. http://dx.doi.org/10.5194/sed-6-2143-2014

[14] Maleki, Z. (2015) The Unique Folding Style in the Zagros Simply Folded Belt, the Kuh-e Qazi Anticline, South Iran. Open Journal of Geology, 5, 514-526.

[15] Maleki, Z., Arian, M. and Solgi, A. (2015) Folding Pattern in the Fars Province, Zagros Folded Belt: Case Study on the Karbasi and Khaftar Anticlines, Interior Fars, Iran. Solid Earth Discussions, 7, 2347-2379. http://dx.doi.org/10.5194/sed-7-2347-2015

[16] Maleki, Z., Arian, M., Solgi, A. and Ganjavian, M.A. (2014) The Elements of Fold Style Analysis in the Khaftar Anticline, Zagros, Iran. Open Journal of Geology, 4, 79-92. http://dx.doi.org/10.4236/ojg.2014.43008

[17] Maleki, Z., Arian, M., Solgi, A. and Ganjavian, M.A. (2015) Elements of Fold Style Analysis in the Karbasi Anticline, Interior Fars Region, Zagros. Geosciences, 24, 293-302. 
[18] Arian, M. and Maleki, Z. (2009) Neotectonic. Asar Nafis Press, Iran, Qom.

[19] Vaseghi, H., Maleki, Z. and Arian, M. (2016) Structural Style in the Zagros Fold-Thrust Belt: The Gavbast Anticline, Coastal Fars. Open Journal of Geology, 6, 109-116. http://dx.doi.org/10.4236/ojg.2016.62011

[20] Baghbanan, A., Maleki, Z. and Pourkemani, M. (2015) Structural Style in the Khalfani Anticline, Coastal Fars, Zagros Fold-Thrust Belt. Open Journal of Geology, 5, 655-665. http://dx.doi.org/10.4236/ojg.2015.59058

[21] Arian, M. (2013) Physiographic-Tectonic Zoning of Iran’s Sedimentary Basins. Open Journal of Geology, 3, $169-177$. http://dx.doi.org/10.4236/ojg.2013.33020

[22] Arian, M. (2011) Basement Tectonics and Geology of Iran. Asar Nafis Press, Qum, 300 p.

[23] Arian, M. (2011) A Preface on Salt Diapirism of Iran. Asar Nafis Press, Qum, 309 p.

[24] Twiss, R.J. and Moores, E.M. (1992) Structural Geology. W.H. Freeman and Company, New York, 532.

[25] Ramsay, J.G. (1967) Folding and Fracturing of Rocks. McGraw-Hill, New York, 568.

[26] Rickard, M.J.A. (1971) Classification Diagram for Fold Orientation. Geological Magazine, 108, 23-26. http://dx.doi.org/10.1017/S0016756800050925

[27] Ragan, D.M. (1985) Structural Geology, an Introduction to Geometrical Techniques. 3rd Edition, John Wiley \& Sons, New York, 210-215.

[28] Setchell, C.M., Cosgrove, J.W. and Liu, J.-G. (2007) The Distribution of Fold Types in the Zagros Simply Folded Belt, Iran. Imperial College London, London. (Map Scale 1:100000)

[29] Tabatabaei, H. (2001) Geological Map of the Zagros, Iran. National Iranian Oil Company, NIOC.

[30] Sepehr, M., Mirhashemi, S.F. and Yavari, M. (2009) Origin of Transfer Faults in the Fars Folded Belt, Zagros Mountains. 1st EAGE International Petroleum Conference and Exhibition Session: Structural Geology and Salt Tectonics I, Shiraz, 4 May 2009.

[31] Letouzey, J. and Sherkati, S. (2004) Salt Movement, Tectonic Events, and Structural Style in the Central Zagros Fold and Thrust Belt (Iran). 24th Annual Gulf Coast Section SEPM Foundation Bob F. Perkins Research Conference, Houston, 5-8 December 2004, 33.

[32] Barzegar, F. (1994) Basement Fault Mapping of Zagros Folded Belt (SW Iran) Based on Space-Born Remotely Sensed Data. Proceeding of the 10th Thematic Conference on Geologic Remote Sensing: Exploration, Environment and Engineering, San Antonio, 9-12 May 1994, 455-466.

[33] Mobasher, K. (2007) Kinematic and Tectonic Significance of the Fold- and Fault-Related Fracture Systems in the Zagros Mountains, Southern Iran. Georgia State University, Atlanta, 144 p.

[34] Yassaghi, A. (2006) Integration of Landsat Image Interpretation and Geomagnetic Data on Verification of Deep-Seated Transverse Fault Lineaments in SE Zagros, Iran. International Journal of Remote Sensing, 27, 4529-4544. http://dx.doi.org/10.1080/01431160600661283

\section{Submit or recommend next manuscript to SCIRP and we will provide best service for you:}

Accepting pre-submission inquiries through Email, Facebook, Linkedin, Twitter, etc

A wide selection of journals (inclusive of 9 subjects, more than 200 journals)

Providing a 24-hour high-quality service

User-friendly online submission system

Fair and swift peer-review system

Efficient typesetting and proofreading procedure

Display of the result of downloads and visits, as well as the number of cited articles

Maximum dissemination of your research work

Submit your manuscript at: http://papersubmission.scirp.org/ 